\title{
Socio-economic and Environmental Impacts of Large-Scale Agricultural Investment in Gambella Region, Ethiopia
}

\author{
Azeb W. Degife, Wolfram Mauser \\ Ludwig Maximilian University of Munich (LMU), Munich, Germany
}

\begin{abstract}
Ethiopian government uses agricultural investment as one of the most important and effective strategies for economic growth, food security, and poverty reduction in the country. Since the mid-2000s, government has awarded millions of hectares of fertile land to foreign companies. This study explores the impact of large-scale agriculture investment and its consequences to local livelihoods in Gambella Region, Ethiopia. Gambella people's survival and their identity are strongly tied to the land and the rivers that run through it. However, currently, foreign and local investors grab the farm area on an industrial scale and that deprives their livelihoods and increases food insecurity. Moreover, large land acquisition has been tremendous environmental devastation in region such as deforestation, biodiversity depletion, and wetlands drained. Meanwhile, socially, people are largely dependent on international food aid and financial assistance. On the other hand, Large Scale Land Acquisitions (LSLA) lead to forced displacement and "villagization" as a result that smallholder farmers are displaced, pastoralists lose the grazing land, and local people lose incomes and livelihoods. Lastly, in the region, due to land corruption, lack of good governance and transparency, the natural resources are depleted and societies become food insecure. Therefore, Ethiopian government's strategies are on the verge of falling unless integrated approach is not implemented.
\end{abstract}

Keywords: agricultural investment, food insecurity, integrated approach, livelihoods

The most common definition of the global land grab refers to large scale land acquisitions (LSLA) by foreign investors either through purchase or lease for agricultural production (Cotula, Vermeulen, \& Keeley, 2009). In Africa, LSLA for the commercial agriculture are the biggest issues. Over the last few years, local and foreign investors have acquired large areas of land in sub-Saharan countries. In the most case, these LSLA are involving countries with serious hunger (food insecurity) problems and the majority of crops grown by foreign investors in developing countries are mainly for export rather than feeding local people (Geary, 2012). Around $70 \%$ of people in Africa and roughly three-fourths of poor people of the continents live in rural areas. These poor rural people depend mainly on agriculture, and increasingly are unable to meet their basic food needs as population pressure on land grows. Recently, resources such as land and water become degraded and agricultural productivity also stagnates (FAO, IFAD and WFP, 2015).

Corresponding author: Azeb W. Degife, Ph.D. student at Geography Department, Ludwig Maximilian University of Munich (LMU), Munich, Germany; research field: physical and environmental geography.

Wolfram Mauser, Ph.D., professor, Chair for Geography and Remote Sensing, Geography Department, Ludwig Maximilian University of Munich (LMU), Munich, Germany; research fields: hydrology, food security and digital farming, remote sensing, development of simulation models. 
In the last few years, international investment in agricultural land has increased globally. In recent times, Ethiopian government uses agricultural investment as one of the most important and effective strategies for economic growth, food security, and poverty reduction in country. Since 1990s, government formulated a long-term economic development strategy called Agriculture Development Led Industrialization (ADLI) which is the government's overarching policy response to Ethiopia's food security and agricultural productivity challenge. The strategy focuses primarily on expansion of large-scale commercial farms and improved productivity in smallholdings (Ethiopian Investment Commission). The Ethiopian government also promotes large-scale agricultural investment as a strategy to improve food security at the national level, through foreign exchange earnings generated by farm outputs; by increased production of crops in the country; and by improved incomes through jobs created on farms (Keeley, Seide, Eid, \& Kidewa, 2014). A few years ago, Ethiopian government identified Gambella Region as one of the regions in Ethiopia which is suitable for agricultural investments and classified most parts of the area as under-utilized. Currently, region has been known for its huge potential for agricultural productions and it possesses enormous arable land suitable to both small-scale and large-scale commercial farming in Ethiopia.

As shown in Figure 1, since the mid-2000s, government has awarded thousands of hectares of most fertile lands of Gambella Region to foreign companies and some of the world's most wealthy individuals to export rice, cotton, seasame, etc., often in long-term leases and at bargain prices. In 2015, Ethiopian Investment Agency (EIA) announced that more than 11.50 million hectares of land have the potential for farming in Ethiopia and made available for agriculture companies that meet Ethiopian government's requirements (Teklemariam, Azadi, Nyssen, Haile, \& Witlox, 2016) and in Gambella alone, 1.2 million hectares of land are available for large-scale farm companies (Rahmato, 2011). According to a World Bank report, in Ethiopia between 2004 and 2009, around 406 large-scale commercial farms investment projects covering 1.19 million hectares were approved (Vhughen \& Gebru, 2013).

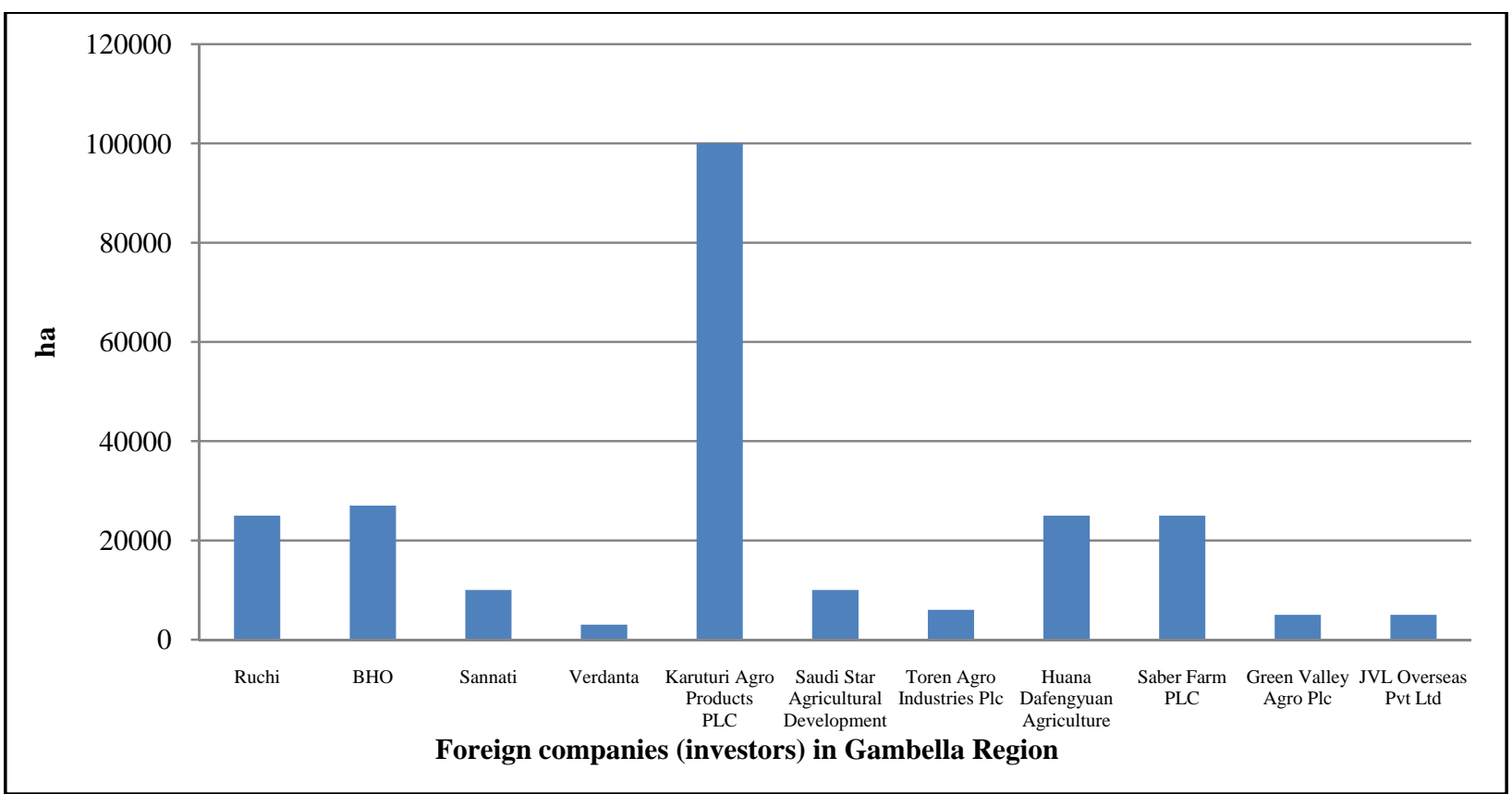

Figure 1. Foreign companies (investors) land acquisition/ha. in Gambella Region [Data sources: Ethiopian Investment Agency (EIA), 2016]. 
Large-scale land acquisition deals take many different forms and it may vary from 1,000 to 500,000 hectares (Onoja \& Achike, 2015). According to recent statistics, Ethiopian government has allocated millions of hectares of land to foreign companies (Rahmato, 2011) although Ethiopia is one of the world's largest recipients of foreign aid. In the year 2015, 10.2 million people in Ethiopia needed emergency food and nutrition assistance; yet in 2010, the Ethiopian government had sold more than 600,000 hectares of agricultural land to transnational companies that export the majority of their production (Cochrane, 2011) to India, Saudi Arabia, and the Gulf Cooperation Council (GCC) states. Currently, over 30\% of the population is below the food poverty line (WFP \& CSA, 2014).

On the other hand, Ethiopian government's strategies and policy of “villagization” program have forcibly displacing hundreds of thousands of indigenous people in order to free up their land so the transnational agro-industry can move in and grow foodstuffs for export. These rushes to land, water, and other essential natural resources in the region particularly have negative effects on indigenous and local people's livelihoods and increasing food insecurity. Currently, indigenous and local people are losing their fertile land and their ability to produce their own food, and thus, they become food insecure and largely dependent on international food aid and financial assistance. From past till present, Gambella people's survival and their identity are strongly tied to the land and the rivers that run through it. For instance, recession of riverside agriculture is common and widely practiced by indigenous people along the Baro, Gilo, and Akobo rivers, particularly cereal crops such as maize, millet, and sorghum crops are cultivated. Yet, the region is generally not cereal self-sufficient; alternative income sources such as fishing are important sources of food. Meanwhile, LSLA also have huge and adverse environmental impacts on the region, particularly forest, wetland, and biodiversity are declining, and both land and water resources are degraded.

Overall, LSLA are a main concern for Ethiopians for recent days. Hence, a range of actions are therefore required to address the threats and challenges of LSLA. Good land governance needs to protect the rights of rural communities, especially vulnerable people, against all "land grabbing" and promoting sustainable agriculture and reducing poverty (Liversage, 2010). However, Ethiopia government is neither strengthening small-scale farmers nor ensuring responsible investment in agriculture. Thus currently, it is difficult for the government to achieve food security and to assure sustainable growth in the country.

\section{Objectives and Research Questions}

This study examines the socio-economic and environmental impacts of large-scale agriculture investment (LSLA) and its consequences on local livelihoods in the region. More specifically, the study will answer the following questions:

(1) What are the social-economic and environmental impacts of the LSLA on local people?

(2) What are the consequences of LSLA to local communities?

\section{Conceptual Framework}

Most of the African labors are engaged in agriculture and depend on land, water, and other natural resources for their livelihoods (Lowder, Skoet, \& Raney, 2016). Around 80\%-85\% Ethiopians are engaged in agriculture, mainly in subsistence and rain-fed farming. The average household land holding in Ethiopia is less than a threshold size of 1.5 hectares and that has adverse impact on food security of farmers (CSA \& World Bank, 2013). For African smallholder farmers, their agricultural production is directly linked to food security. 
Sometimes, farmers are exposed to adverse weather conditions and natural disasters in the period between harvests which result in them being vulnerable to food insecurity and drought (The World Bank, 2007).

The key issue is now whether the prospects for food security and poverty reduction in developing countries, and globally in general, are better with or without agriculture investments, and what are the best ways to maximize benefits and avoid negative effects on agriculture investments in sub-Sahara countries. For a continent that is quite used to being exploited, small-scale farmers have to be a priority, as well as protecting Africa and making sure the continent benefits equally from global investors. Otherwise, farmers of developing country will be the first victims of the present rush for land. According to various reports, it indicates that in less than a year, foreign investors and companies acquired around 56 million hectares of land globally (Deininger \& Byerlee, 2011). Of these, above half of them (29 million ha.) were in sub-Saharan Africa countries (Lehavi, 2015).

World Development Movement (WDM) published a report also in April 2014 titled "Carving up a Continent”. It underlines that the multinational corporations take over African food systems and farming lands. According to the report, multinational companies have signed agreements with a number of African countries to establish agriculture investment under the aspect of fighting poverty and food insecurity (Mwesigire, 2014). This report also provides evidence that multinational corporations come at the expense of small-scale African food producers and instead of providing a solution to hunger, multinational corporations exacerbate hunger and poverty through increased land-grabbing, insecure and poorly paid jobs, the privatization of seed, and a focus on producing for export markets rather than feeding local populations (National Institute for African Studies [NIAS], 2016). According to Global Development (2010), research findings have indicated that a million Chinese farmers have joined the large-scale farm investment in Africa to satisfy food security of their people, and moreover, world's richest countries also involve in buying or leasing land in Africa to produce bio-fuel (Onoja \& Achike, 2015).

Agriculture investments can be "win-win" rather than "neo-colonialism” in sub-Sahara Africa countries only when agricultural investments are generating a wide range of benefits such as increasing productivity and food security, employment creation, poverty reduction, technology transfer, and access to capital and markets (Liu, 2014). In general, macro-level benefits may be increased by agriculture investment (GDP growth, greater government revenues), and create opportunities for raising local living standards and therefore agriculture investments play an important role in catalyzing economic development in rural areas in Africa (Cotula, 2011). However, the socio-environmental impacts of agricultural investment are not well understood or not well recorded. Agricultural investments need to integrate socio-environmental and economic aspects and that can support sustainable development in a country. Hence, land, water, biodiversity, and other environmental resources should be considered whenever large-scale agricultural land is allocated and that can help ensure the long-term sustainability of ecosystem services and livelihoods of rural people. Figure 2 shows the conceptual framework which shows the positive and the negative impacts of LSLA. 


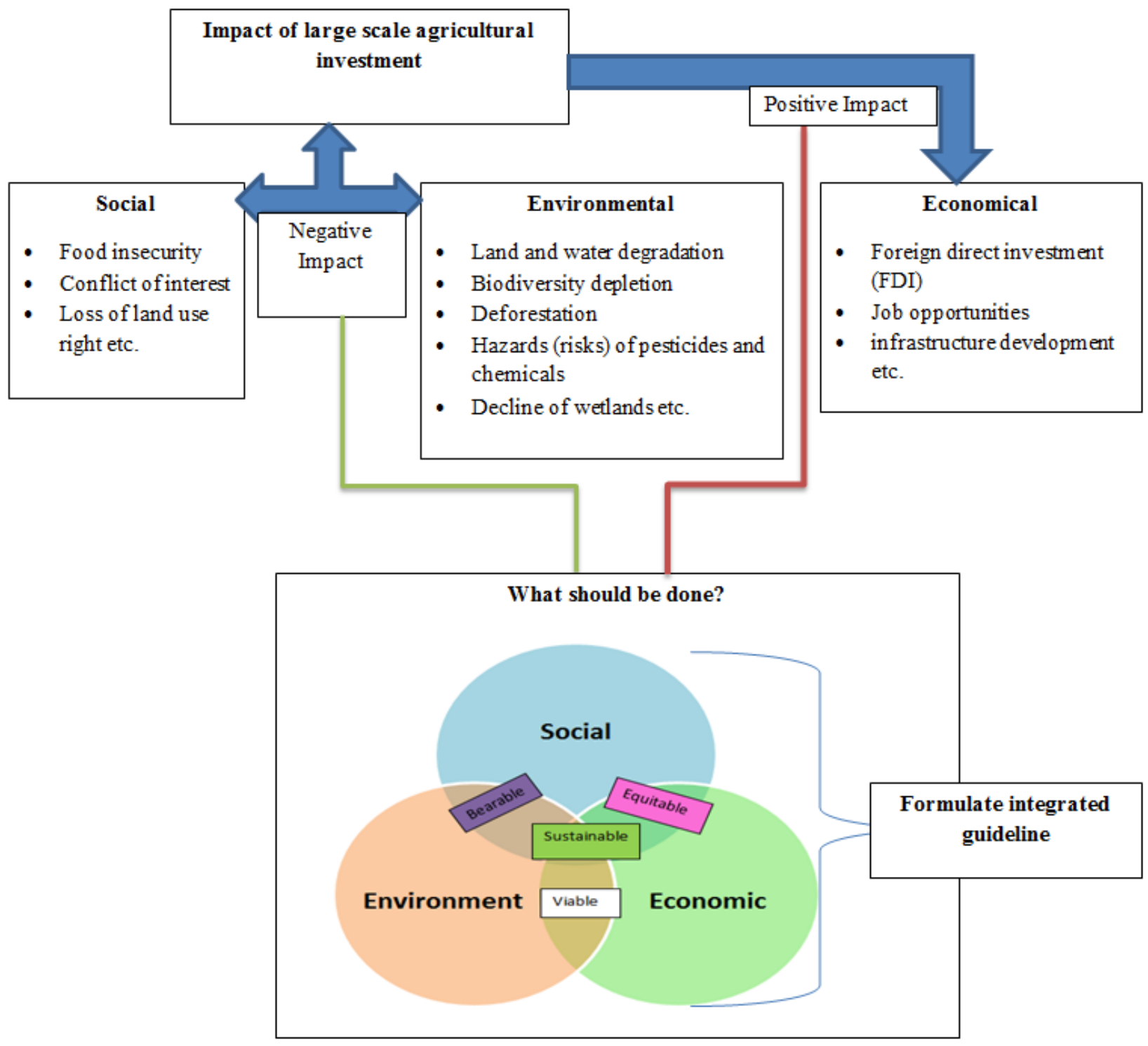

Figure 2. Conceptual framework.

\section{Methods of Data Collection}

This paper relies on the data set from the Gambella Region of Ethiopia which is located in the south-western part of Ethiopia between the geographical coordinates $6^{\circ} 28^{\prime} 38^{\prime \prime}$ to $8^{\circ} 34^{\prime}$ north latitude and $33^{\circ}$ to $35^{\circ} 11^{\prime} 11^{\prime \prime}$ east longitude as indicated in Figure 3. The region is bounded to West and Northwest by the Republic of South Sudan (Behailu et al., 2011). Gambella Region is one of the nine ethnic divisions or regions of Ethiopia. It is composed of two administrative zones and eight small administrative units. The area of the region is 29,783 square kilometers with estimated population of over 307,096 inhabitants [CSA (Central Statistical Agency), 2007). Within the region, Gambella National Park covers approximately 5,061 square kilometers or $19.6 \%$ of the region's territory. The topography of the region is divided into two broad classes, which are the lower piedmonts between 500 to 1,900 masl (meters above sea level) and the flood plains of below 500 m contours. Baro, Gilo, Akobo, and Alwero are the main rivers crossing the Gambella Region. 

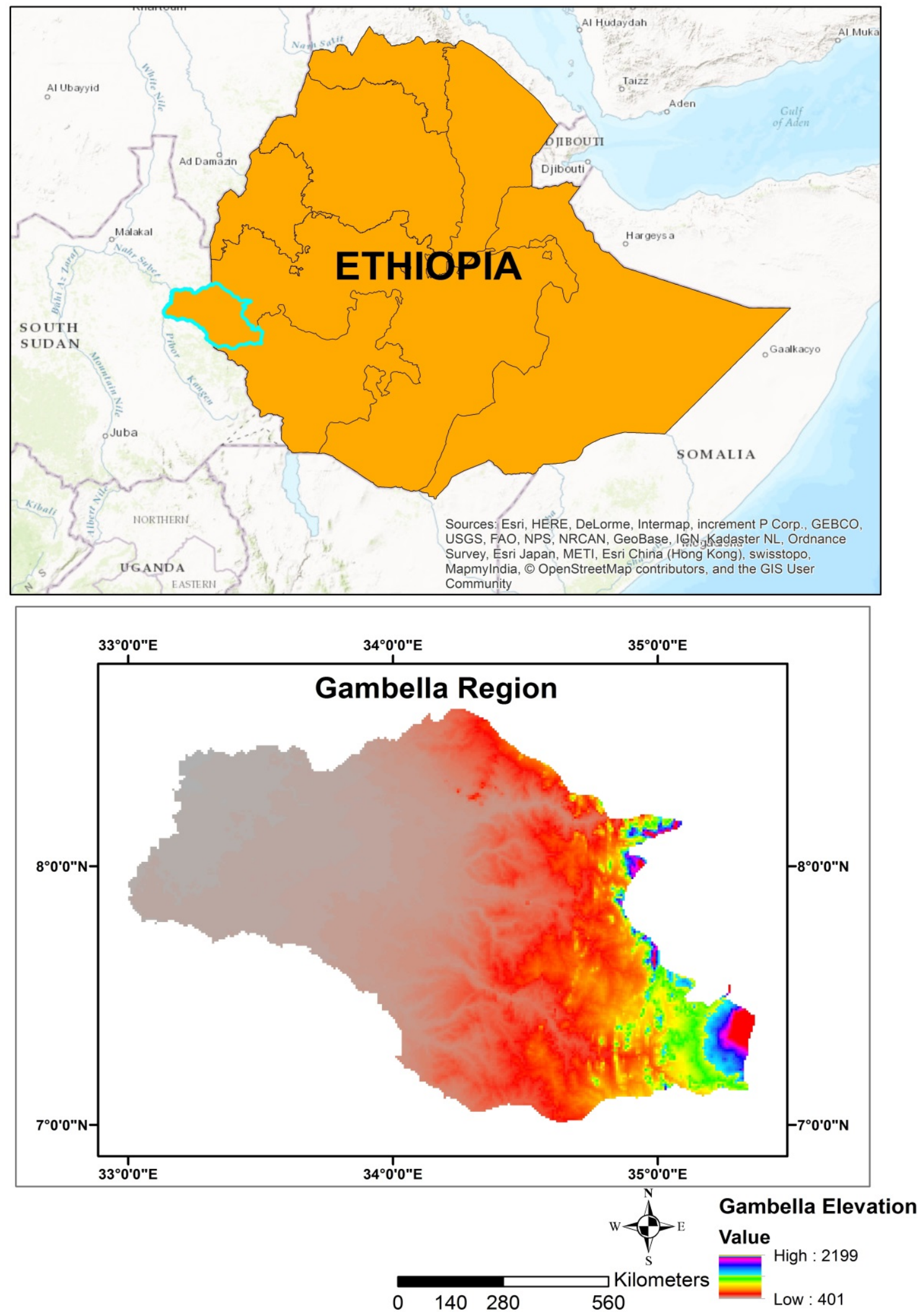

Figure 3. Study area (top: relative location within Ethiopia, bottom: digital elevation model of Gambella Region OCHA, 2015). 
The main motivation of the research is to understand in depth social-economic and environmental impacts of LSLA in Gambella Region, moreover, to understand the intense interaction and conflict of various stakeholders (governments, foreign and local investors, small-scale farm holder, and local and indigenous people) that are directly related or affected by LSLA. Therefore, from the fieldwork, the primary data are generated through interview, direct observation, documentary analysis, and a focus group discussion. In addition to the primary data, the secondary data are acquired through the European environmental satellite Sentinel-2, government reports, and published documents.

Various reports underline that Ethiopian government allotted large scale of land to local and foreign investors within the old boundary of Gambella National Park. Figure 4 shows a GPS recording which is undertaken at various location of the study area in order to confirm if any agricultural activities are undertaken within the park. At each sample, the following information was collected or recorded:

(1) Type of land use: e.g. cotton, sesame, and rice;

(2) Intensification level: e.g. fertilizer input, technological input (tractor);

(3) Farm structure: e.g. commercial farm, smallholder farm, and subsistence farm;

(4) Farming practices: e.g. irrigation, rainfed, etc.

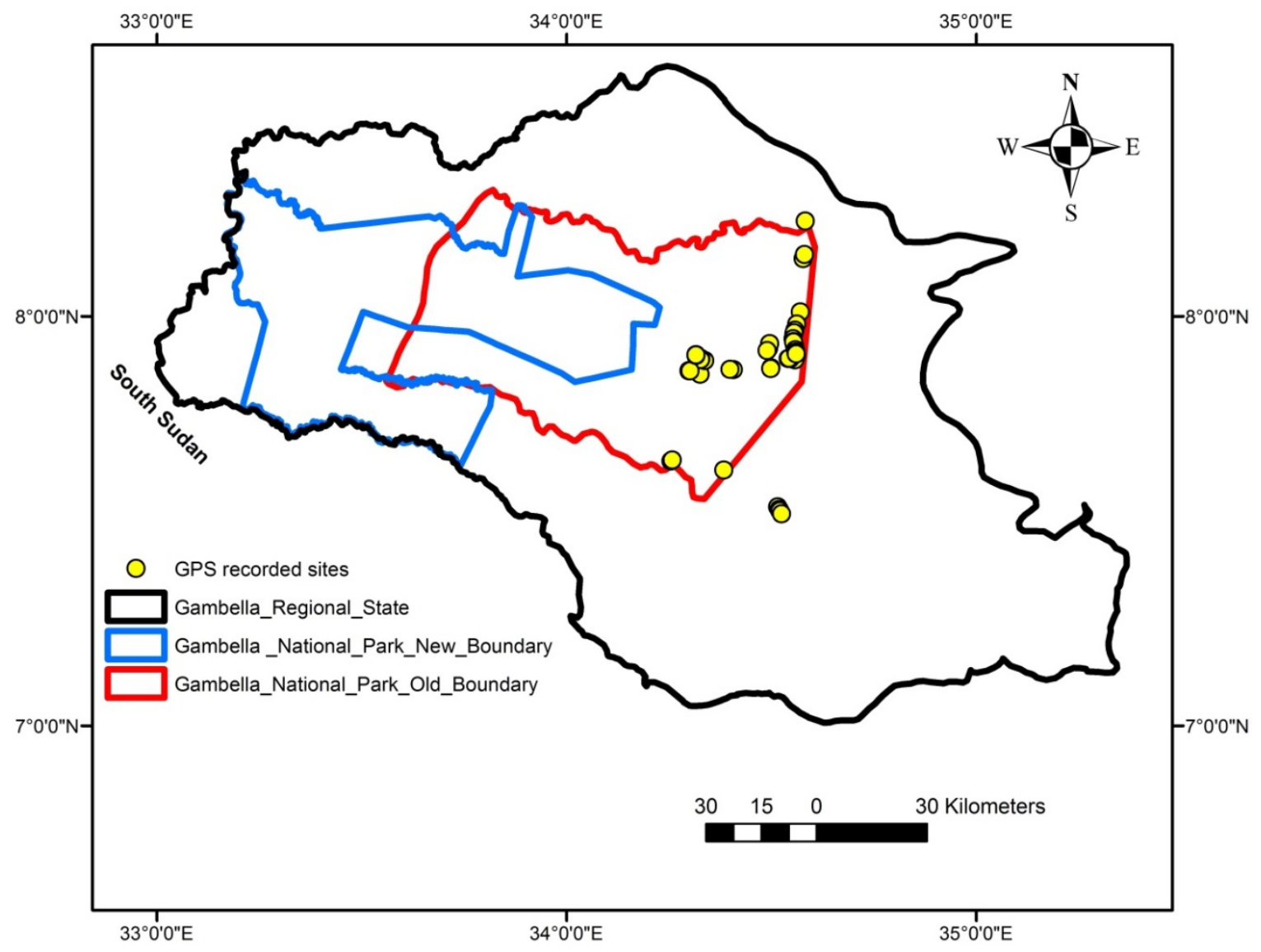

Figure 4. GPS recorded sites in study area (Source: Fieldwork).

LSLA are changing landscapes of Gambella National Park. Huge areas of virgin land of Gambella National Park have been transformed into foreign-owned agribusiness ventures and local investors. These 
LSLA are infringing on Gambella National Park boundaries. Hence, new Gambella National Park boundary is drawn up by Ethiopian government in 2016. The old Gambella National Park boundary was totally covered by $5,061 \mathrm{~km}^{2}$ from total area of $29,783 \mathrm{~km}^{2}$ but now the new boundary covers around 4,403 $\mathrm{km}^{2}$ of the total area of the region.

\section{Causes of Large Scale Land Acquisitions (LSLA) in Gambella Region}

Three reasons can be identified to drive LSLA in Gambella Region:

(1) Suitability for agricultural investment: Natural constraints are limiting the land's suitability for agriculture and cultivation practices. Natural conditions such as local climatic, soil, and topographic conditions determine the available energy, water, and nutrient supply for agricultural crops. Besides natural constraints, complex interactions of social, economic, political, and cultural aspects determine whether and how land is used for agriculture (Zabel, Putzenlechner, \& Mauser, 2014). Ethiopia has varied agro-climatic zones and this diversity makes it favorable and suitable for growing a variety of crops (Gebresllassie, Gashaw, \& Mehari, 2014). Gambella Region is one the most fertile regions in Ethiopia and is suitable for growing a variety of crops. Also, numbers of rivers are flowing and used for irrigation in the region. A few decades ago, a huge irrigation dam was constructed on the Alwero River. The reservoir can hold 80 million cubic metres of water which is projected to develop 10,000 hectares of land in the area. According to Zabel et al. (2014), finding indicates that Ethiopia in general and Gambella Region in particular have been moderate to high land's suitability for agriculture and cultivation practices. Figures 5 and 6 show that the crop suitability index indicates that Gambella Region has high crop suitability compared with other parts of the Ethiopia (Zabel et al., 2014).

\section{Crop Suitability Index of the Ethiopia and Gambella Region During 1981-2010 and 2011-2040}

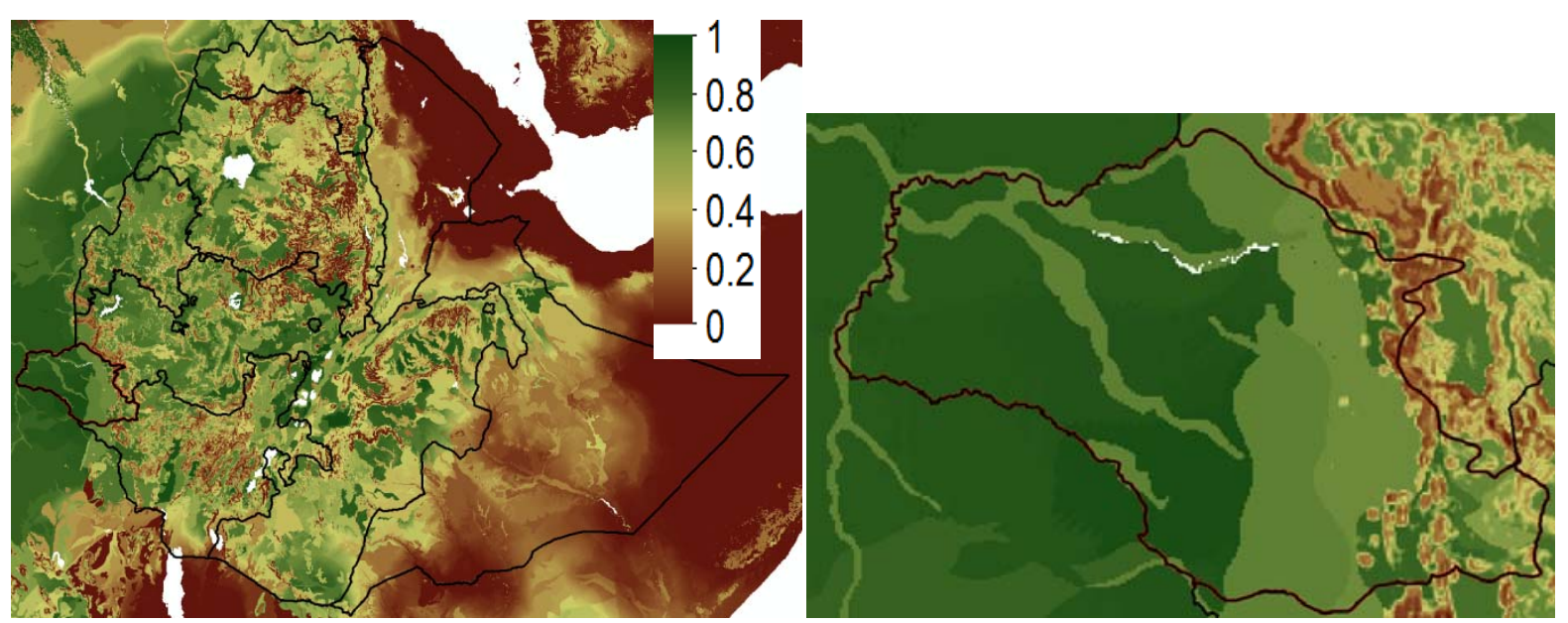

Figure 5. Ethiopian (left) and Gambella Region (right) agricultural suitability considering rainfed conditions and irrigated areas (1981-2010).

Note. A crop suitability index of 1 indicates very high suitability, 0 means no suitability for cropping. 


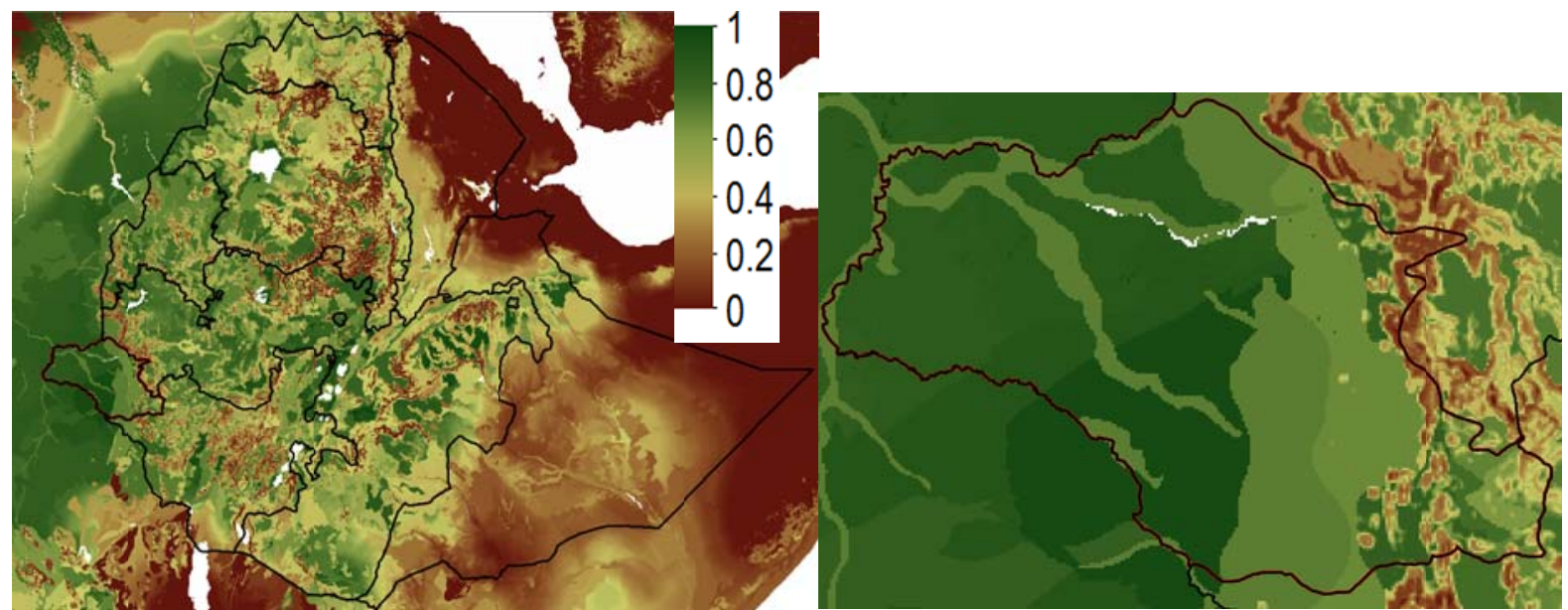

Figure 6. Ethiopian (left) and Gambella Region (right) agricultural suitability considering rainfed conditions and irrigated areas (2011-2040) for the A1B climate change scenario (Zabel et al., 2014).

(2) “Unused and/or underutilized” land: The Ethiopian government ignores Gambella’s customary rights and claims and most parts of Gambella Region's land are "underutilized” or “underdeveloped”. As a result, tenure security is low and land grabs are very common in the region (Besada, 2016).

(3) Ethiopia government's policy: Ethiopia government's main interest is to increase foreign currency earning, to expand the agro-industrial companies, to create job opportunities and better infrastructure, and as well to reduce both poverty and the country's chronic food insecurity. Hence, Ethiopia government's strategy primarily focuses on the promotion of agricultural-led industrialization and expansion of labor intensive industries [FDRE (Federal Democratic Republic of Ethiopia), 2016].

\section{Results and Discussion}

Here listed the main findings of a preliminary analysis of the data collected:

(1) One of the perceived benefits of large-scale commercial agriculture is the massive amount of wage employment that these operations will provide. According to Gambella Regional State Bureau of Finance and Economic Development, between 2005 and 2013, labor force participation rate of the region increased from $51.3 \%$ to $68.4 \%$. During the same period, unemployment in the region declined from $25.6 \%$ to $4.4 \%$. However, the majority of these jobs are laborer positions, which provide low wages, are often seasonal and short-term in nature. In addition, the casual workers are deprived of various work benefits including maternity leave and sick leave (Yassin, 2014). On the other hand, massive influxes of laborers, usually men, from other areas of the country can have significantly adverse effects on local communities. During the interviews, many people expressed their concern that laborers will stay after their employment, acquire land, eventually bring their families and relatives, and further aggravate pressures on the land and resources in the region. As the researchers also observed in the fieldwork, employees of large-scale farm companies such as Saudi Star and Toren Agro Industries PLC came from various parts of Ethiopia rather than the local or indigenous people. However, in recent times, women from local people are taking significant proportion of employment in these large companies although salary is insignificant. Generally, poorly paid work on the large-scale farms plus environmental degradation and a failure to deliver on promises of better infrastructure cause conflict between investors and local people. The main interests of the local and indigenous people are to sustain their food security and to access natural resources such as water, land, and forest resources without any rival. 
(2) After 1991, Ethiopian government has been developing a new strategy to achieve economic growth in the country. The strategy called ADLI that sees agriculture as the engine of growth. ADLI's main objectives are to: improve agricultural extension services, promote better use of land and water resources, enhance access to financial services, improve access to domestic and export markets, and provide rural infrastructure (MOFEC \& MOA, 2010). The Ethiopian government's economic development strategy ADLI also has distinctive features that include: commercialization of smallholder agriculture through product diversification, a shift to higher-valued crops, and promotion of niche of high-value export crops. As prior strategic investment, Ethiopian government has identified several higher-valued crops such as organic coffee, cotton, tobacco, sugar cane, tea, spices, and oil seeds (peanuts and sesame). According to Ethiopian Investment Commission (EIA), government strongly restricted local and foreign investors neither to cultivate nor to sale any kind of cereal crops to local market and this is mainly due to the fact that $85 \%$ of Ethiopian farmers are subsistence farmers and their incomes are highly depending on producing and selling cereal crops to local market. However, in a few special cases, EIA gives permission to the investors to cultivate cereal crops. For instance, Saudi Star PLC produces new hybrid rice called New Rice for Africa (NERICA) and currently also Saudi Star is producing high-quality standard rice known as Basmati rice and it exports into the Middle East countries especially to Saudi Arabia. In recent times, the main objective of Ministry of Agriculture and Natural Resources was to increase the agro-industrial sector of the country rather than empowering small-scale farmer.

(3) National park and forests are the sources of food for the Gambella people (Nuer and Anuak people). Recently, however, both regional and federal governments allocated large areas of land to foreign and local investors within the national park. Currently, large areas of virgin land, formerly the Gambella National Park, have been transformed into plantations for rice, sugar cane, and palm oil by foreign-owned agri-business ventures and companies. Thus, a great extent of land use change is observed in the landscapes of Gambella Region. For instance, Saudi Star rice farm which owned 10,000 hectares has largely cleared forest and savanna that were commonly understood to be a part of Gambella National Park. According to the Ethiopian Wildlife Conservation Authority (EWCA), in 2008, around 438,000 hectares of land have been awarded to investors in the vicinity of the Gambella National Park and all lands have been allotted without Environmental Impact Assessments (Oakland Institute, 2011). As the researchers observed also from the fieldwork and also Figure 7 shows, large-scale farm companies are located within the Gambella National Park wetlands with abundant fish populations and bird life presently being altered for rice production while extensive forest cover in nearby areas has been completely cleared without consultation of communities. According to International Union for the Conservation of Nature and Natural Resources (IUCN), Gambella National Park is categorized as protected area. However, the park is currently invaded by large-scale farm companies. Since 2016, the Ethiopian government is developing new Gambella National Park boundary and relocates the boundary from central part to western and southwestern part of the region. 


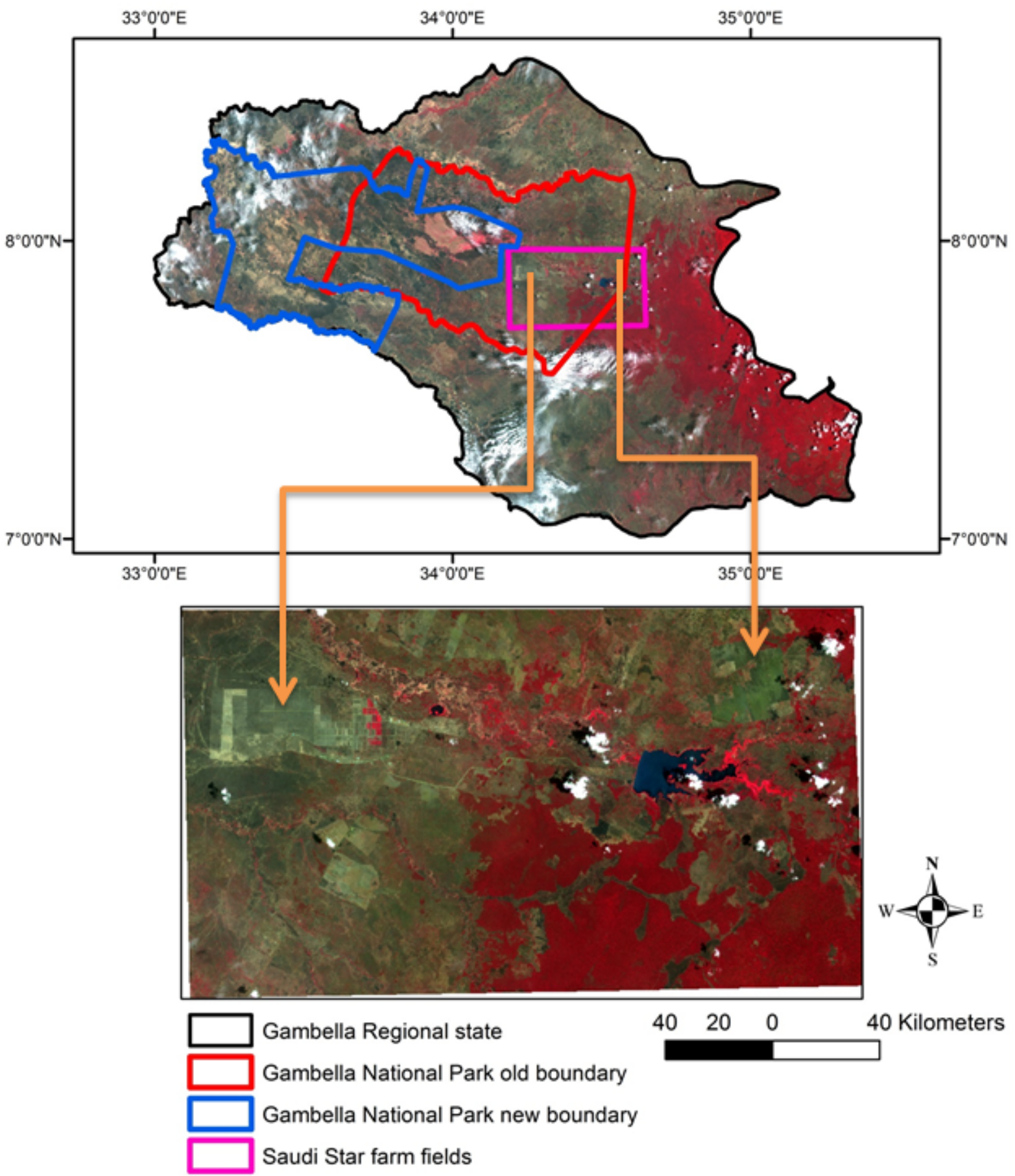

Figure 7. Large-scale commercial farmers (such as Saudi Star and Ruchi PLC) have acquired thousands of hectares of lands within the old boundary of Gambella National Park. The main types of crops under cultivation are rice, millet, sesame, and cotton. Further, Alwero dam which was completed in 1992 and is used for large-scale farm irrigation is also situated within the park (Source: Sentinel 2A satellite image, acquired from March 16, 2017 and fieldwork). 
(4) According to recent statistics from the regional investment office (as illustrated in Figure 8), less than 5\% of the large agricultural investment projects are operational while the others are at various implementation and preimplementation stages. Evidence suggests that, LSLA in Ethiopia have small benefit, especially when the company only utilizes a small share of the land that it has acquired. Particularly in study area after acquisition of the land, both foreign and local investors are cutting and clearing the forest and savanna, however, they are not actively involved in operation or operate small portion from the total land covered by crops. As a result, through time, environmental degradation is observed in the region, particularly natural resources such as land, water, forests, and biodiversity are depleted.

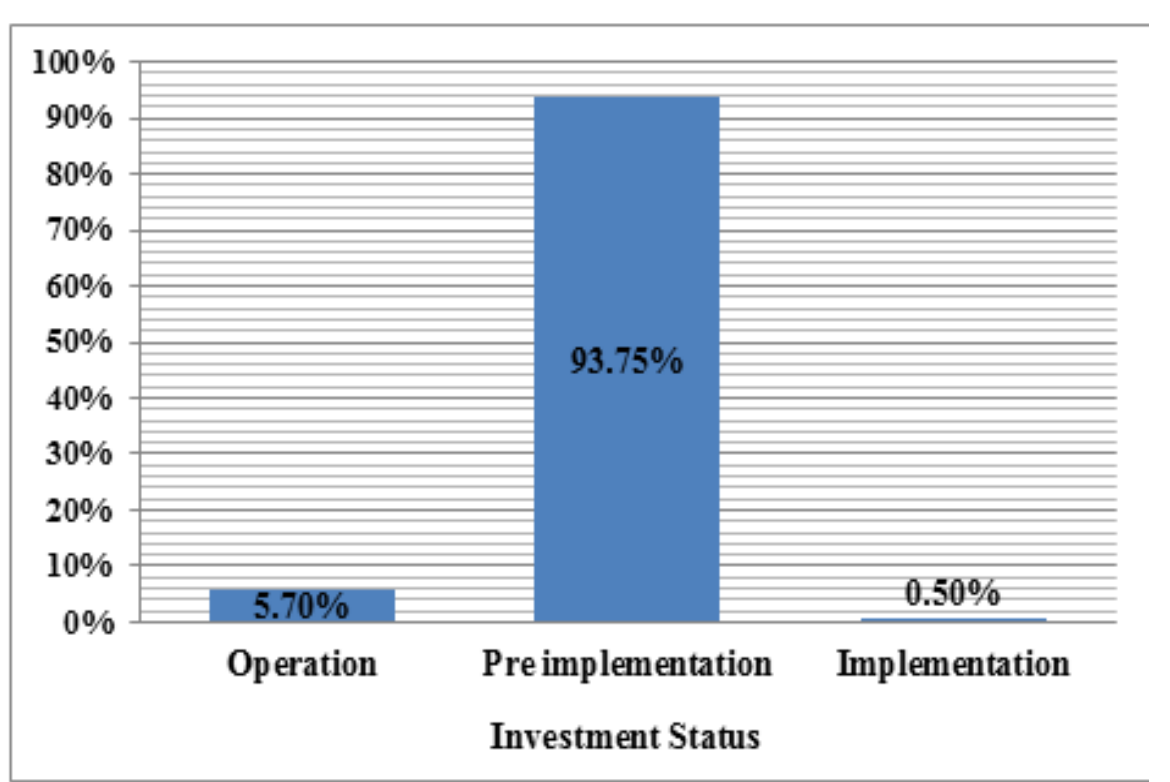

Operation: When investors
covered partially or small
portion of the land that they
acquired by crops and as well
the investors highly motivates
to cover the total land by crops
Preimplantation: when
investors grant permission
from the Ethiopian investment
office but not yet involved in
farming practices (crop
cultivation)
Implementation: when the
investors actively involved in
farming practices over the total
land that they acquired

Figure 8. List of licensed investment projects (agriculture sector in Gambella Region) since March 25, 1993 to December 25, 2015 (Source: Ethiopian Investment Agency, 2016).

(5) A few years ago, land investments were controlled by both federal and regional governments. However, that caused problems related to overlap in the granting of land, provision of loans, and investors' capabilities. Hence, to solve this problem, the federal government has established a centralized agency called the Ethiopian Agriculture Investment and Land Administration Agency (EAILAA). The tasks of the agency are both to control and follow through all land investment activities and the offering of land for large-scale agricultural investments in Ethiopia. This leads to discontent among Gambella regional government officials. Thus, most recently, the struggle between the two entities (EAILAA officials and Gambella regional government officials) resulted in an information gap and a lack of adequate information about the land allocation. For instance, a key informant mentioned that a particular land was given to more than one investor at time and that caused disputes among investors. In order to solve the problem, government took responsibility and paid compensation and resolved the disputes. On the other hand, corruption and bribes in the large-scale land investment have also often occurred due to informational gaps and lack of coordination between regional and federal government offices. Recent studies underline that both federal and regional government officials are highly involved in land sector corruption. Forest and reserved areas are allotted to the investors without Environmental Impact Assessment and consent of the society. In 2002, Ethiopian government adopted the Environmental Impact Assessment Proclamation No. 299, and since then, some efforts have been made to implement the law by the 
Environmental Protection Authority (EPA) and the relevant regional environmental offices, which were themselves established by Proclamation No. 295 of 2002. In spite of these efforts, EIA in Ethiopia has until now remained weak (Damtie \& Bayou, 2008). As a result, both destruction of natural resources and endangerment of the local people's livelihoods and assets were observed during the fieldwork. Land governance focused on poor rural people's food security and ensuring sustainable livelihoods that are essential for people and countries that rely on land as one of their main economic, social, and cultural assets. In Gambella, people are being forcibly relocated from their land by government. According to higher officials, "villagization" projects are designed to improve access to basic amenities. However, evidence suggests that in the region, government has been involved in forced population movements and development-induced displacements. Small-scale farmers and pastoralist lose their lands and they are forced to migrate from rural areas to neighboring countries such as Sudan, Kenya, and if possible the global north (notably to Europe) to sustain their lives.

In general, large-scale commercial farm investment has negative impacts on social and environmental aspects of the Gambella Region. Natural resources such as forest, water, and land are degraded and local and indigenous people are exposed to food insecurity. However, Ethiopian government underlines that large-scale commercial farm has economic benefits for the country, and as a result, large-scale agricultural investment is highly expanding in the region.

\section{Conclusions}

Gambella Region has immense potential for agricultural production and has enormous and precious land resources suitable to both small-scale and large-scale commercial farming. A few years ago, government identified Gambella Region as one of the regions in Ethiopia which is suitable for agricultural investments and classified most parts of the area in the region as under-utilized. Due to abundant water resources and fertility of soil, Ethiopia government's policy (ADLI) aggravates LSLA in the region. The ADLI strategy exacerbates expansion of large-scale commercial farms in Ethiopia at the expense of small-scale farmers or local people. In the past decades, Ethiopian government has awarded millions of hectares of most fertile land to foreign companies to produce and export crops primarily to India, Saudi Arabia, and the GCC states, which helped improve Ethiopian FDI (Foreign Direct Investment). However, since 2000, both federal and regional government allotted large-scale commercial agricultural lands within Gambella National Park boundary; hence, the park is currently invaded by large-scale farm companies. Consequently, investors are clearing the forest and savanna which results in environmental degradation in the region. In 2016, government demarcated a new Gambella National Park boundary, shifting the park form central to western and southwestern part of the region.

On the other hand, recently, large areas of land were transformed into foreign-owned agribusiness ventures and companies without the consent of the society. As a result, people are forcedly displaced from their land. The resettlement sites were allocated without considering the biophysical factors, such as soil fertility and the availability of grazing land. Hence, currently, small-scale farmers and pastoralists are migrating to neighboring countries.

Corruption and bribes are key issues in the large-scale land investment in the Gambella Region. It frequently occurs due to informational gaps and lack of coordination between regional and federal government offices. Currently, both federal and regional government officials are highly involved in the land sector 
corruption which poses great obstacles for ensuring the integrity and effectiveness of initiatives related to natural resource management in the region and which directly affects the people's livelihood. Until now, the government has not yet formulated a "push back" policy and law of enforcement to handle corruption. Meanwhile, Ethiopian government is not continuously monitoring the activities on the land allotted both with respect to compliance to the environment and social laws. At last, large-scale farm can have economic benefits; however, it has negative impacts on the society's livelihood and environment. The three pillars of sustainability (economic, social, and environment) need to be incorporating one another and the Ethiopian government needs to compel to an integrated approach that fully considers the interest of small-scale farmer and local/indigenous people. In this way, the Ethiopian government's strategy, ADLI, can be successful (achieve its goals) and Ethiopian people can be alleviated from food insecurity and poverty.

\section{References}

Behailu, H., Tsedal, M., Jemal, A., Katckos, G., Weshik, R., Asere, G., ... Umode, U. (2011). Action plan of adaptation to climatic change. Ethiopia: Gambela People’s Regional State, Land-Use-Land Allotment Authority.

Besada, H. G. (Ed.). (2016). Governing natural resources for Africa's development. New York, NY: Routledge.

Cochrane, L. (2011). Food security or food sovereignty: The case of land grabs. The Journal of Humanitarian Assistance, Tufts University, Feinstein International Center. Retrieved http://logancochrane.com/images/pdf/Food-Security-or-Food-Sove reignty---The-Case-of-Land-Grabs---JHA-2011.pdf

Cotula, L. (2011). Land grab or development opportunity? International farmland deals in Africa. Bogotá: Colombia FDI Perspectives.

Cotula, L., Vermeulen, S., Leonard, R., \& Keeley, J. (2009). Land grab or development opportunity? Agricultural investment and international land deals in Africa. London and Rome: IIED/FAO/IFAD. Retrieved http://pubs.iied.org/pdfs/12561IIED.pdf

CSA \& World Bank. (2013). Ethiopia Rural Socioeconomic Survey (ERSS) report. Retrieved http://siteresources.worldbank. org/INTLSMS/Resources/3358986-1233781970982/5800988-1367841456879/9170025-1367841502220/ERSS_Survey_Rep ort.pdf

CSA (Central Statistical Agency). (2007). Ethiopia-Population and Housing Census of 2007.

Damtie, M., \& Bayou, M. (2008). Overview of environmental impact assessment in Ethiopia: Gaps and challenges. Addis Ababa, Ethiopia: MELCA Mahiber. Retrieved https://chilot.files.wordpress.com/2011/01/overview-of-eia-book-html.pdf

Deininger, K., \& Byerlee, D. (2011). Rising global interest in farmland: Can it yield sustainable and equitable benefits? Washington, D.C.: The World Bank Publications.

FAO, IFAD and WFP. (2015). The state of food insecurity in the world 2015. Meeting the 2015 international hunger targets: Taking stock of uneven progress. Rome: FAO.

FDRE (Federal Democratic Republic of Ethiopia). (2016). Country strategy paper 2016-2020. African Development Bank Group.

Geary, K. (2012). Our land, our lives: Time out on the global land rush. Oxfam Policy and Practice: Private Sector, 9(2), 1-26.

Gebresllassie, H., Gashaw, T., \& Mehari, A. (2014). Wetland degradation in Ethiopia: Causes, consequences and remedies. Journal of Environment and Earth Science, 4(11), 40-48.

Keeley, J., Seide, W. M., Eid, A., \& Kidewa, A. L. (2014). Large-Scale land deals in Ethiopia: Scale, trends, features and outcomes to date. London: IIED.

Lehavi, A. (2015). Land law in the age of globalization and land grabbing. In M. Graziadei and L. Smith (Eds.), Comparative property law: Global perspectives (pp. 290-310). Edward Elgar Publishing.

Liu, P. (2014). Impacts of foreign agricultural investment on developing countries: Evidence from case studies. FAO Commodity and Trade Policy Research Working Papers No. 47, Rome. Retrieved http://www.fao.org/3/a-i3900e.pdf

Liversage, H. (2010). Responding to "land grabbing" and promoting responsible investment in agriculture. IFAD Occasional Paper, 2, 1-12. Retrieved https://www.ifad.org/documents/10180/c7d51222-fbf3-41d1-b72c-2df3912f9b41

Lowder, S. K., Skoet, J., \& Raney, T. (2016). The number, size, and distribution of farms, smallholder farms, and family farms worldwide. World Development, 87, 16-29.

MOFEC \& MOA. (2010). Agricultural growth program (GAFSP Gap Financing). 
Mwesigire, B. (2014). Land grabbing in Africa, the new colonialism. Retrieved https://thisisafrica.me/land-grabbing-africanew-colonialism/

National Institute for African Studies (NIAS). (2016). Carving up a continent: How the UK government is facilitating the corporate takeover of African food systems. Retrieved http://africanstudies.org.uk/africa-uk-foodsystems-post-entry/

Oakland Institute. (2011). Understanding land investment deals in Africa. Retrieved https://www.oaklandinstitute.org/sites/ oaklandinstitute.org/files/OI_Ethiopa_Land_Investment_report.pdf

OCHA (United Nations Office for the Coordination of Humanitarian Affairs) Ethiopia. (2004). Ethiopia-Elevation model. Retrieved https://data.humdata.org/dataset/ethiopia-elevation-model

Onoja, A. O., \& Achike, A. I. (2015). Large-Scale land acquisitions by foreign investors in West Africa: Learning points. Consilience: The Journal of Sustainable Development, 14(2), 173-188.

Rahmato, D. (2011). Land to investors: Large-Scale land transfers in Ethiopia. Addis Ababa, Ethiopia: Forum for Social Studies.

Teklemariam, D., Azadi, H., Nyssen, J., Haile, M., \& Witlox, F. (2016). How sustainable is transnational farmland acquisition in Ethiopia? Lessons learned from the Benishangul-Gumuz Region. Sustainability, 8(3), 213.

The World Bank. (2007). World development report 2008: Agriculture for development. Washington, D.C.: The World Bank.

Vhughen, D., \& Gebru, A. (2013). Large-Scale acquisitions of land in Ethiopia. Retrieved http://www.focusonland.com/down load/51c498dca2e07/

WFP \& CSA. (2014). Comprehensive Food Security and Vulnerability Analysis (CFSVA). Addis Ababa, Ethiopia: Central Statistical Agency (CSA) \& World Food Programme (WFP).

Yassin, A. (2014). Transnational large scale agricultural firms in Gambella Regional State, Ethiopia: Local potentials, opportunities and constraints for market linkage and contractual farming schemes. Brighton, UK: Future Agricultures Consortium.

Zabel, F., Putzenlechner, B., \& Mauser, W. (2014). Global agricultural land resources-A high resolution suitability evaluation and its perspectives until 2100 under climate change conditions. PLoS One, 9(9), e107522. 